(C) 1981. The Genetical Society of Great Britain

\title{
THE GIEMSA C-BAND KARYOTYPES OF SIX LOLIUM SPECIES
}

\author{
H. M. THOMAS
}

Welsh Plant Breeding Station, Aberystwyth, Dyfed, U.K.

Received 10.ix.80

\section{INTRODUCTION}

THE genus Lolium includes both inbreeding and outbreeding species. All are diploid with 14 chromosomes. With conventional staining the karyotypes are similar and not easily distinguishable from each other. Comparisons of the karyotypes have previously been made by Malik and Thomas (1966). Rees and Jones (1967) and recently Hutchinson et al. (1979) compared DNA amounts and found that the three inbreeding species had about 40 per cent more DNA than the outbreeding species. By examining $L$. perenne and $L$. temulentum more closely, Rees and Jones (1967) found that these differences are probably due to lengthwise duplication of base sequences within the chromosomal DNA.

Chromosome morphology can be regarded as a taxonomic character and, in the same way as comparisons of plant morphology and chromosome pairing of hybrids, its study can clarify species relationships. The use of the Giemsa C-band technique has shown new features of chromosome morphology, making visible chromosome differences and similarities not previously apparent.

Several comparative studies of the chromosome banding of related species have been carried out, notably by Singh and Röbbelen (1975) in Secale and by Vosa (1976) in Hordeum. The Giemsa C-band karyotype of L. temulentum has been published previously (Thomas, 1977). In the present study this is presented together with the C-band karyotypes of the five other species.

\section{Materials and Methods}

Seed from the collections maintained at the Welsh Plant Breeding Station were germinated and the plants obtained kept in a glasshouse. The six species studied were: L. temulentum (Ba 9006), L. remotum (Ba 8315), L. loliaceum (Ba 5164), L. rigidum (Ba 9344), L. perenne (S. 24), L. multiflorum (Bb 1276).

Vegetative tillers were placed in an aerated culture tank to produce actively growing roots. At least five genotypes were examined from each species.

The treatment originally used for $L$. temulentum (Thomas, 1977) was modified somewhat (original shown in brackets). Root tips were pretreated in distilled water at $1^{\circ} \mathrm{C}$ for $16 \mathrm{~h}$, fixed in ethanol : acetic acid $(3: 1)$ for $1-3 \mathrm{~h}$, softened in $1 \mathrm{~N} \mathrm{HCl}$ at $60^{\circ} \mathrm{C}$ for $30 \mathrm{sec},(0 \cdot 2 \mathrm{~N} \mathrm{HCl}$ for $2 \mathrm{~min})$ and then squashed in 45 per cent acetic acid. The preparations were frozen, the coverslips removed and the slides air-dried. They were then stored in darkness at room temperature until the following day. 
Slides were immersed in 45 per cent acetic acid at $60^{\circ} \mathrm{C}$ for $20 \mathrm{~min}$, rinsed in tap water and placed in a saturated solution of barium hydroxide at $10^{\circ} \mathrm{C}$ for $20 \mathrm{~min}$ (room temperature for $5 \mathrm{~min}$ ). The slides were thoroughly rinsed in tap water for $5 \mathrm{~min}$ and in $2 \times \mathrm{SSC}$ for $5 \mathrm{~min}$ at room temperature, then placed in $2 \times \mathrm{SSC}$ at $60^{\circ} \mathrm{C}$ for $45 \mathrm{~min}(1 \mathrm{~h})$. They were rinsed, air-dried and stained in 2 per cent Giemsa solution for 10 min (Gurr's improved R66 in Sorensen buffer, $p \mathrm{H} \mathrm{6.9),} \mathrm{again} \mathrm{rinsed,} \mathrm{air-dried} \mathrm{and} \mathrm{mounted} \mathrm{in} \mathrm{Canada}$ balsam. Photographs and drawings were taken of selected cells and transferred to metric paper.

\section{Results}

The banding patterns in all six species are similar in that most bands are associated with either the centromere or the secondary constriction. However, the slightly modified technique stained some intercalary bands not previously seen (fig. 1). The chromosomes are numbered on gross chromosome morphology, i.e., presence of nucleolus organiser regions, chromosome length and arm ratios, but chromosomes with similar numbers in different species are not necessarily homoeologous. The total length of the chromosome complement is about 40 per cent greater in the inbreeding than in the outbreeding species. The total length of C-banding in the chromosome complement varies from $2.75 \mu \mathrm{m}(4.9$ per cent) in $L$. perenne to $6.00 \mu \mathrm{m}(7.8 \mathrm{per}$ cent) in L. temulentum (table 1$)$. Though there are some differences in the size of the bands, variation in total C-band length is mainly due to the different number of bands in the karyotypes.

\section{Discussion}

In terms of their banding patterns $L$. temulentum and L. remotum are very similar, differing in only one chromosome. This fits in with the results of hybridisation studies, which have shown them to be very closely related. In fact Jenkin (1954) regarded them as one species.

The banding pattern of $L$. loliaceum bears little resemblance to the other two inbreeders, except in so far as it has two bands on chromosome 2. Otherwise the banding pattern has more in common with the three outbreeders, differing from $L$. multiflorum in only two chromosomes. This similarity with the outbreeders is interesting considering the DNA value of this species (Hutchinson et al., 1979) which is intermediate between the outbreeders on the one hand, and $L$. temulentum and $L$. remotum on the other.

$L$. perenne and $L$. rigidum have the same banding pattern; they do however differ in chromosome length. Although the gross chromosome morphology of $L$. multiflorum is very similar to $L$. perenne there are differences in the banding patterns of chromosomes 5, 6 and 7 .

Though total chromosome length varies by only about 40 per cent between the six species, the total length of C-bands is more than twice as great in L. temulentum and L. remotum as it is in L.perenne (table 1 ). When the total chromosome length of $L$. perenne is subtracted from the total chromosome length of each of the other species, and the same done with the length of the C-bands we obtain the supplementary chromosome length and 
Plate I

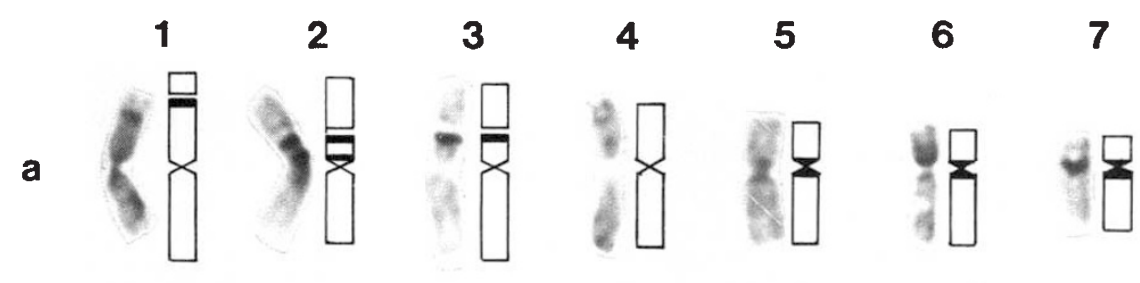

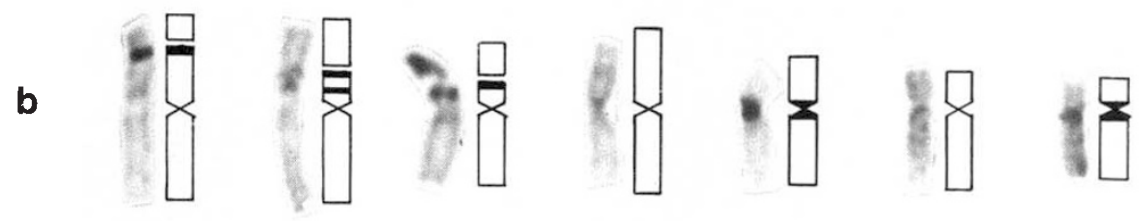

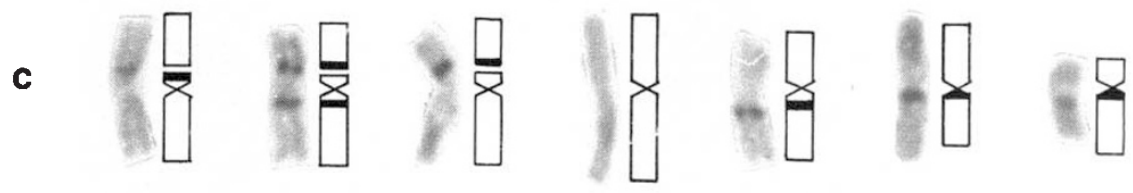

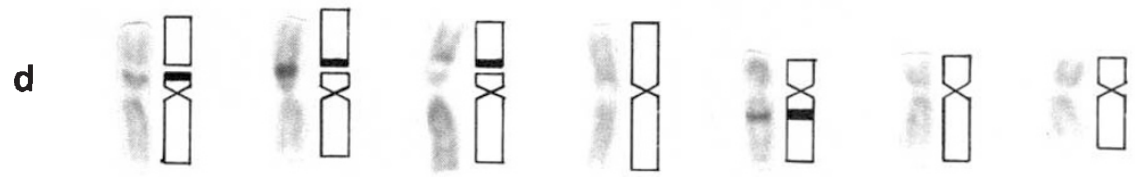

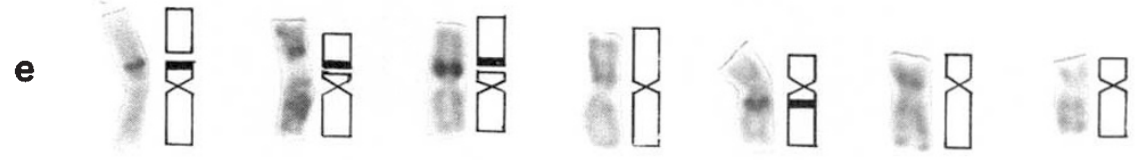

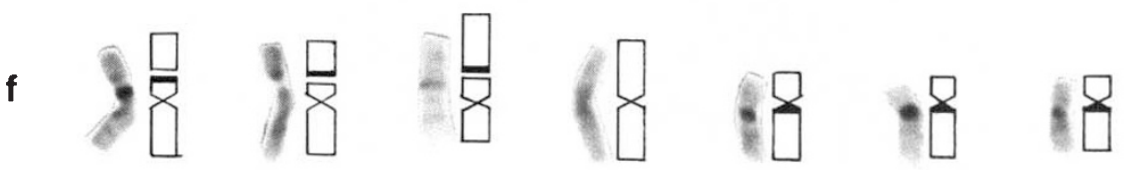

Fig. 1.-The Giemsa C-band karyotypes of six Lolium species. (a) L. temulentum, (b) $L$. remotum, (c) $L$. loliaceum, (d) $L$. rigidum, (e) $L$. perenne, (f) $L$. multiflorum. 
TABLE 1

Length of chromosomes and bands in the six Lolium species

\begin{tabular}{|c|c|c|c|c|c|}
\hline Species & $\begin{array}{c}\text { Total } \\
\text { chromosome } \\
\text { length }(\mu \mathrm{m})\end{array}$ & $\begin{array}{l}\text { Total length of } \\
\text { C-bands }(\mu \mathrm{m})\end{array}$ & $\begin{array}{l}\text { Supplementary } \\
\text { chromosome } \\
\text { length }\end{array}$ & $\begin{array}{l}\text { Supplementary } \\
\text { C-band length }\end{array}$ & $\begin{array}{c}\text { DNA/ } \\
\text { nucleus } \\
\left(_{(\mathrm{pg})^{3}}\right.\end{array}$ \\
\hline L. temulentum & $77 \cdot 0$ & $6 \cdot 00$ & $20 \cdot 5$ & 3.25 & $6 \cdot 23$ \\
\hline L. remotum & $79 \cdot 0$ & $5 \cdot 00$ & $22 \cdot 5$ & $2 \cdot 25$ & $6 \cdot 04$ \\
\hline L. loliaceum & $72 \cdot 5$ & $5 \cdot 00$ & $16 \cdot 0$ & $2 \cdot 25$ & $5 \cdot 49$ \\
\hline L. rigidum & $65 \cdot 5$ & 3.00 & $9 \cdot 0$ & 0.25 & $4 \cdot 33$ \\
\hline L. perenne & $56 \cdot 5$ & $2 \cdot 75$ & - & - & $4 \cdot 16$ \\
\hline L. multiflorum & $57 \cdot 25$ & $4 \cdot 25$ & 0.25 & $1 \cdot 5$ & $4 \cdot 31$ \\
\hline
\end{tabular}

${ }^{1}$ Total chromosome length minus chroms. length of $L$. perenne.

${ }^{2}$ Total C-band length minus length of C-bands of $L$. perenne.

${ }^{3}$ Data from Hutchinson et al. (1979).

the supplementary C-band length (table 1). It is clear that the supplementary chromosome length in the inbreeders consists proportionally of twice as much C-banding as does the chromosome complement as a whole.

Hutchinson et al. (1979) found that among the Lolium spp., L. perenne had the smallest amount of nuclear DNA. The DNA in the other species over and above this amount they call supplementary DNA. In a series of interspecific hybrids they discovered that this supplementary DNA had little effect on phenotype.

The length of the C-bands is of course approximate, the measurements having been taken from enlarged photographs. However these figures can provide a rough indication of the DNA in the two types of chromatin shown. By taking the total length of $\mathrm{C}$-band heterochromatin, plus the total length of euchromatin (total chromosome length minus the length of C-bands) for each species, and relating them to the DNA/nucleus for each species (Hutchinson et al., 1979), we obtain by "least squares" the DNA per unit length of $\mathrm{C}$-band heterochromatin and euchromatin. These were calculated to be: $0.05368 \mathrm{pg} \mathrm{DNA} / \mu \mathrm{m}$ of euchromatin and $0.38831 \mathrm{pg} \mathrm{DNA} / \mu \mathrm{m}$ of heterochromatin. This shows that $\mathrm{C}$-band heterochromatin in Lolium has 7.2 times as much DNA per unit length as euchromatin. These figures represent the average concentration of DNA in the two types of chromatin seen; there may of course be further variation within each type. This is a much greater difference than that found in Lathyrus for example (Rees and Narayan, 1977), and while one might expect differences between genera, in this case it may in part be due to the different methods used. In Lathyrus the values were obtained from measurements of heterochromatic areas of interphase cells, while the present figures are based on Giemsa stained bands in metaphase chromosomes.

Knowing the amount of DNA per unit length of both types of chromatin we can estimate the total DNA located in each, for all six species. Figure 2 shows these values plotted against the total nuclear DNA per species. The linear regressions are significant at the 1 per cent and 2 per cent levels for euchromatic and heterochromatic DNA respectively. The slopes are the same, showing that for each picogram increase in euchromatic DNA there is 


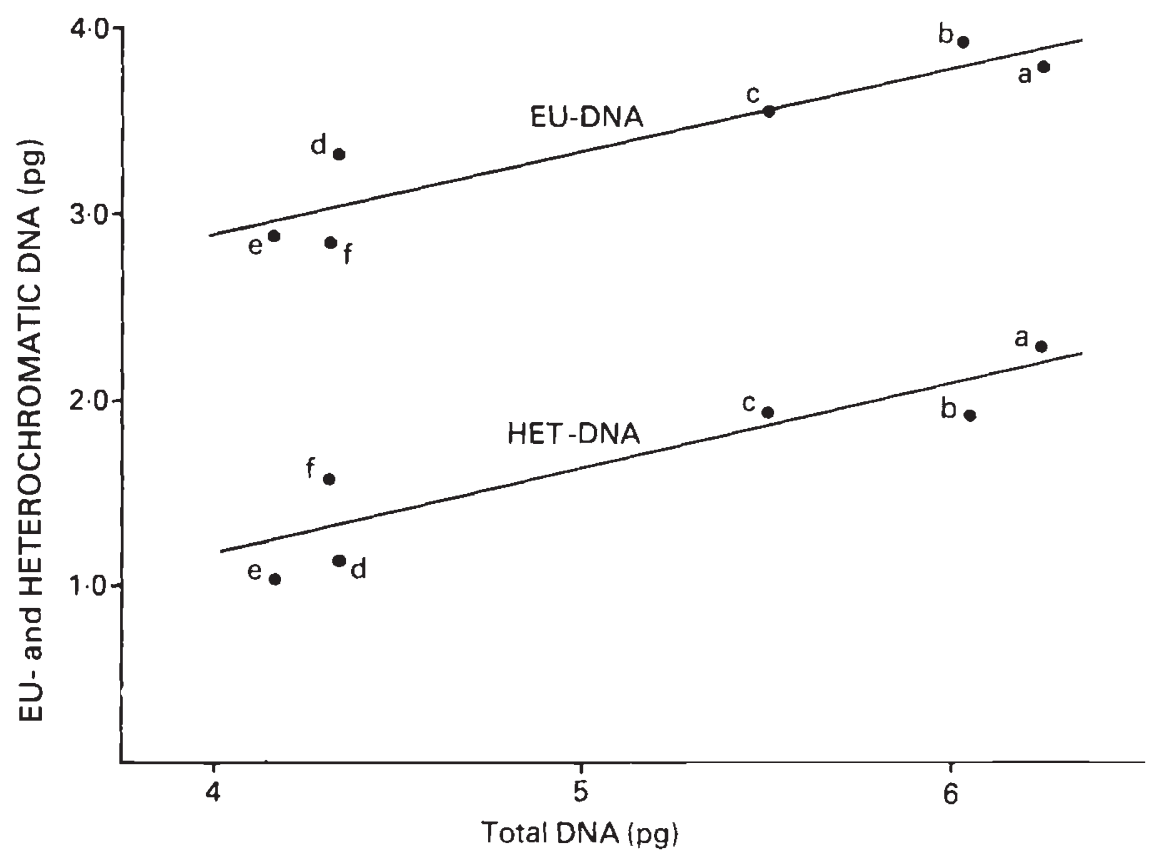

FIG. 2.-Euchromatic and heterochromatic DNA in Lolium plotted against total nuclear DNA. (a) L. temulentum, (b) L. remotum, (c) L. loliaceum, (d) L. rigidum, (e) L. perenne, (f) L. multiflorum.

an equal increase in heterochromatic DNA. This means that on average supplementary DNA is half euchromatic and half heterochromatic DNA.

A striking exception to this trend is the DNA difference between $L$. perenne and $L$. multiflorum. The supplementary DNA in this case is exclusively located in the heterochromatin. When the banding patterns of the two species are examined more closely it is clear that the increase in heterochromatic DNA is due mainly, if not entirely, to the bands on chromosomes 6 and 7 of L. multiflorum which are absent in L. perenne.

Species differentiation in Lolium has been accompanied by changes in gross chromosome morphology and chromosome banding patterns. The heterochromatin varies between species not only in distribution but also quantitatively. While the proportion of heterochromatin is greater in those species with most DNA, the actual changes in DNA throughout the genus is due equally to changes in euchromatic and heterochromatic DNA.

Acknowledgements.-My thanks to Mrs M. R. Meredith for maintaining the vegetative material and for her invaluable help; also to Professor H. Rees, Department of Agricultural Botany, UCW, Aberystwyth, for his critical reading of the manuscript.

\section{REFERENCES}

HUTCHINSON, J., REES, H., AND SEAL, A. G. 1979. An assay of the activity of supplementary DNA in Lolium. Heredity, 43, 411-421. 
JENKIN, T. J. 1954. Interspecific and intergeneric hybrids in herbage grasses. VIII. Lolium loliaceum, Lolium remotum and Lolium temulentum, with references to "Lolium canadense". J. Genet., 52, 318-331.

MALIK, C. P., AND THOMAS, P. T. 1966. Karyotypic studies in some Lolium and Festuca species. Caryologia, 19, 167-196.

REES, H. AND JONES, G. H. 1967. Chromosome evolution in Lolium. Heredity, 22, 1-18.

REES, H., AND NARAYAN, R. K. J. 1977. Evolutionary DNA variation in Lathyrus. Chromosomes Today, 6, $131-139$.

SINGH, R. J., AND RÖBBELEN, G. 1975. Comparison of somatic Giemsa banding pattern in several species of rye. Z. Pflanzenzüchtg, 75, 270-285.

ThOMAS, H. M. 1977. Giemsa banding in Lolium temulentum. Can. J. Genet. Cytol., 19, 663-666.

vosA, C. G. 1976. Chromosome banding patterns in cultivated and wild barleys (Hordeum spp.). Heredity, 37, 395-403. 